\title{
Habitats of native and exotic plants in Colorado shortgrass steppe: a comparative approach
}

Post-print/Accepted manuscript

Peter M. Kotanen

Joy Bergelson

Donald L. Hazlett

Kotanen PM, Bergelson J, Hazlett DL. 1998. Habitats of native and exotic plants in Colorado shortgrass steppe: a comparative approach. Can. J. Bot. 76: 664-672 doi:10.1139/b98-036

\section{HOW TO CITE TSPACE ITEMS}

Always cite the published version, so the author(s) will receive recognition through services that track citation counts, e.g. Scopus. If you need to cite the page number of the TSpace version (original manuscript or accepted manuscript) because you cannot access the published version, then cite the TSpace version in addition to the published version using the permanent URI (handle) found on the record page. 
January 26, 1998

BOT 97-153

\section{Habitats of native and exotic plants in Colorado shortgrass steppe: a comparative approach}

\section{Peter M. Kotanen ${ }^{1}$}

Department of Ecology and Evolution, The University of Chicago, 1101 East 57th St., Chicago, IL 60637, USA

\section{Joy Bergelson}

Department of Ecology and Evolution, The University of Chicago, 1101 East 57th St., Chicago, IL 60637, USA

\section{Donald L. Hazlett}

Box 345, Pierce, CO 80650, USA

${ }^{1}$ Correspondence author. Present address and address for correspondence: Department of Botany, University of Toronto at Mississauga, 3359 Mississauga Road North, Mississauga, Ontario, L5L 1C6, CANADA

E-mail: pkotanen@credit.erin.utoronto.ca

Telephone: 905-828-5365

FAX: 905-828-3792 


\begin{abstract}
Invading species often are close relatives, and therefore share many characteristics as a consequence of their common ancestry. This tends to confound studies of invasions, since many irrelevant characteristics are likely to be correlated with a species’ geographic origin (alien or native). We address this problem by using phylogenetically independent comparisons to investigate the habitat characteristics of plants of the Central Plains Experimental Range (Colorado, USA). We initially show that exotic species are more likely than natives to occur in riparian zones, roadsides, and disturbed sites, and less likely to occur in grassland. The relationship between exotic origins and disturbed sites disappears when phylogenetic dependence is removed from the analyses; in contrast, the other associations persist following phylogenetic detrending, indicating that aliens and their native relatives consistently differ in their ability to exploit riparian, roadside, and grassland habitats. Our results indicate that disturbed sites currently are dominated by only a few groups of related exotic ruderals, while the ability to exploit roadsides and riparian zones has been and may continue to be important for the success of many taxa of invaders.
\end{abstract}

Key words: biological invasions, comparative methods, disturbance, grasslands, phylogeny 


\section{Introduction}

Deliberate and accidental introductions of non-native plants by humans have profoundly altered many natural systems. Exotics now comprise 25\% or more of the species of many regional floras (Heywood 1989; Vitousek et al. 1996). Most of these exotics are innocuous, but others have significantly altered the structure and function of the ecosystems they have invaded (e.g., Mediterranean annual grasses in California: Heady 1988; Sims 1988; Heady et al. 1992; D’Antonio and Vitousek 1992; Myrica faya in Hawai'i: Vitousek et al. 1987; Vitousek and Walker 1989; Vitousek et al. 1996). Like most well-established (naturalized) invaders, these species probably are impossible to eliminate, and may have changed the affected systems permanently.

Predicting the risk of invasion has proven to be a difficult challenge (Crawley 1986, 1987; Pimm 1987; Lodge 1993; Mack 1996). Still, most reviews agree that exotics tend to be non-randomly distributed with respect to habitat; for example, disturbed areas are widely considered to be especially vulnerable to plant invasions (Elton 1958; Mooney and Drake 1986; Crawley 1986, 1987; Drake et al. 1989; Pimm 1991; Hobbs and Huenneke 1992; Huston 1994; Cronk and Fuller 1995). This result suggests that the ability to exploit a disturbed site may be an important predictor of a potential invader. Not all plants have this ability; to prosper in a disturbed site may require a ruderal life history, good dispersal ability, rapid growth, the ability to tolerate physical stresses, or other traits which can be liabilities in undisturbed environments (Grime 1979; Sousa 1984; Pickett and White 1985).

One potential problem with interpreting such patterns of invasion is that much evidence comes from case histories of one or a few troublesome species or genera, and this may present a biased perspective (see McIntyre and Lavorel 1994; Thompson 1994; Crawley et al. 1996; Williamson and Fitter 1996 for some recent exceptions). A second problem stems from the fact that exotic plants often are relatives (but see Williamson 1996; Williamson and Fitter 1996 for an opposing view). For example, even after 
correcting for familial species richness, Asteraceae, Brassicaceae, Poaceae, and Fabaceae contribute disproportionately many invaders (Baker 1974; Crawley 1987; Heywood 1989; Daehler and Strong 1993; Cronk and Fuller 1995; Ruesink et al. 1995; Mack 1996). Consequently, exotics can share numerous traits (including those related to habitat requirements) as a result of common ancestry, whether or not these traits are directly related to invasiveness. This may seriously confound analyses of ecological differences between natives and exotics (Felsenstein 1985; Ridley 1989; Harvey and Pagel 1991, Harvey and Purvis 1991; Gittleman and Luh 1992; Miles and Dunham 1993; Ackerly and Donoghue 1995; Ackerly 1997).

In recent years, there has been a proliferation of methods designed to address this problem (Felsenstein 1988; Brooks and McLennan 1991; Harvey and Pagel 1991; Harvey and Purvis 1991; Gittleman and Luh 1992; McKitrick 1993; Miles and Dunham 1993). These methods differ in detail, but all attempt to reduce a multispecies dataset to a set of independent contrasts, which enables tests for associations among characters without the confounding influence of relationship. Most applications of these techniques have involved analyses of evolutionary associations, usually within well-defined clades, but these methods also are proving useful to biologists who are interested in understanding the ecology and organization of complex communities (Miles and Dunham 1993; Ackerly 1997).

In this paper, we discuss the occurrence of alien plant species in a landscape still dominated by natives: the Central Plains Experimental Range in north-central Colorado. We have taken the "extended phenotype” view (Dawkins 1982), treating each plant's ability to exploit different habitats as a complex, polygenic, inherited trait, which is itself the product of numerous other traits including life history, growth rate, seed production, and dispersal. In this view, habitat requirements are not fundamentally different from other complex traits like size or behaviour. We compare the success of aliens and natives in different habitats, consider how these habitat associations 
contribute to invasiveness, and suggest ecological reasons for the observed patterns. Specifically, we address two principal questions:

1. Do alien and native plants have similar habitat associations, or are aliens associated with particular habitats to a greater degree than natives?

2. Do these associations persist even when the confounding influence of relationship is removed?

To answer these questions, we have performed one of the first formal phylogenetic analyses comparing the aliens and natives of an entire vascular flora. To date, only one other study (Crawley et al. 1996) has adopted a similar approach; ours is the first such investigation to consider a North American flora. 


\section{Methods}

\section{$\underline{\text { Study Site and Flora }}$}

This study is based on the vascular flora of the Central Plains Experimental Range (CPER) (40 $\square 49^{\prime} \mathrm{N}, 107 \square 47^{\prime} \mathrm{W}, 1660$ m ASL, ca. 60 km northeast of Fort Collins, Colorado, USA). This 6280 ha area, a research site since 1937, is set within the much larger Shortgrass Steppe Long-Term Ecological Research site. Most of the CPER is dominated by the drought- and grazing- tolerant bunchgrass, Bouteloua gracilis ${ }^{1}$, and is used for grazing by cattle.

Compared to many North American grasslands, shortgrass steppe has been little penetrated by exotics (Mack and Thompson 1982; Heady 1988; Sims 1988; Mack 1989; Heady et al. 1992). Still, the 1995 CPER plant checklist includes 52 non- North American exotics (Table 1), as well as 285 species believed to be native to North America. For both natives and exotics, this tally includes locally persistent species as well as transients (Pyßek 1995), but excludes species which were planted locally but have failed to spread. Most CPER species are herbaceous dicots, graminoids, or dwarf shrubs; the only tree which occurs locally is cottonwood, Populus deltoides. The checklist's habitat data allowed us to classify each plant species as primarily occurring in up to five non-exclusive habitat types: "roadside” (roads, trails, and their margins), “riparian” (watercourses, generally with trees), “ravine” (eroded but dry slopes and valleys), “disturbed” (severely physically perturbed by factors such as construction and trampling around water tanks and salt blocks), and "grassland" (grazed but otherwise undisturbed grassland). This checklist is available from the Shortgrass Steppe website ${ }^{2}$.

\section{Constructing the Trees}

\footnotetext{
${ }^{1}$ Nomenclature follows Great Plains Flora Association (1986).

2 Shortgrass Steppe Long-Term Ecological Research project. (1997, January 15). SGS Home Page. <http://sgs.cnr.colostate.edu/sgshome.html> (1998, February 26).
} 
While detailed molecular phylogenies are rapidly becoming available for relatively small clades, the membership of most plant communities is so taxonomically diverse that reliable community-level phylogenies will not be available in the forseeable future (Chase et al. 1993; Baum 1994). Instead, we have employed a robust analysis of two alternative but approximate classification schemes. We recognize that both of these phylogenetic trees contain errors, and therefore present them as contrasting hypotheses.

The first (FGP) classification is based on the hierarchically nested taxonomic system (species, genus, family, etc.) of the Flora of the Great Plains (Great Plains Flora Association 1986), which itself is arranged according to Cronquist (1981). This flora is unusual in that it does not subdivide Poaceae into subfamilies, tribes, or subtribes; we therefore have relied upon Clayton and Renvoize (1986) for these subdivisions. This first classification represents the resolution and accuracy available in many regional floras.

We constructed the second (Chase) classification by arranging families according to the Search II strict consensus tree of Chase et al. (1993). This tree is based on sequence data of the chloroplast gene $r b c \mathrm{~L}$, and is one of the taxonomically broadest molecular phylogenies (499 species) yet estimated for flowering plants. It is known not to be the most parsimonious possibility; however, Donoghue and Ackerly (1996) found that comparative analyses based on 7670 slightly more parsimonious variants of this tree produced very similar results. We omitted 11 small families ${ }^{3}$ containing 22 CPER species because Chase et al. (1993) did not include them or reported them as being extremely fragmented, and fused 4 closely related pairs of families ${ }^{4}$ identified by Chase

\footnotetext{
${ }^{3}$ Agavaceae, Cactaceae, Equisetacae, Geraniaceae, Juncaginaceae, Liliaceae s.l., Loasaceae, Marsiliaceae, Orobanchaceae, Plantaginaceae, Salicaceae

${ }^{4}$ Amaranthaceae + Chenopodiaceae, Boraginaceae + Hydrophyllaceae, Brassicaceae + Capparidaceae, Lamiaceae + Verbenaceae
} 
et al. (1993) as mutually polyphyletic or paraphyletic. With these exceptions, this second classification is identical to the FGP tree below the familial level; it reflects the manner in which molecular techniques are changing the "traditional” view of superfamilial relationships. See Crawley et al. (1996) for a similar approach.

\section{$\underline{\text { Statistical Analyses }}$}

We have analyzed our data using a modification of the simple but robust comparative method proposed by Burt (1989) (q.v. Felsenstein 1985, 1988; Armstrong and Westoby 1993). In this method, groups of related species are defined in such a way that each group provides a single alien vs. native contrast, statistically and phylogenetically independent of all similar contrasts (Fig. 1). This method is suitable for poorly-known phylogenies since it assumes no particular evolutionary model, does not attempt to reconstruct ancestral character states, does not require knowledge of branch lengths, and allows polytomies and discrete characters (Burt 1989; Felsenstein 1985, 1988; Harvey and Purvis 1991; Miles and Dunham 1993; Purvis and Rambaut 1995b).

We identified the required contrasts using the BRUNCH routine of CAIC 2.0 (Purvis and Rambaut 1995a,b), with origin (alien or native) designated as an independent variable. This produced a unique set of phylogenetically independent contrasts for each classification. Each contrast, $\mathrm{C}_{\mathrm{i}}$, was evaluated as:

$$
\mathrm{C}_{\mathrm{i}}=\mathrm{p}_{\mathrm{ai}}-\mathrm{p}_{\mathrm{ni}}
$$

where $\mathrm{p}_{\mathrm{ai}}=$ the proportion of aliens in contrast $i$ which have successfully occupied habitat $x, \mathrm{p}_{\mathrm{ni}}=$ the proportion of natives in contrast $i$ which have successfully occupied habitat $x$, and where $x$ might represent, for example, riparian zones (Fig. 1). Each contrast ranges from -1 to +1 ; a positive value indicates that aliens are more likely to be associated with habitat $x$ than natives, a negative association indicates the converse, and 
0 indicates no association. We conservatively followed Burt (1989) and Felsenstein (1985, 1988) in using sign tests to determine whether each set of phylogenetically independent contrasts differed significantly from 0 . To test for associations in the original, uncorrected dataset, we used standard $\mathrm{X}^{2}$ tests (origin $\square$ occurrence in habitat $x)$. 


\section{Results}

\section{$\underline{\text { Raw (uncorrected) results }}$}

Aliens comprised about $15 \%$ of the 337 locally-recorded plant species; however, some families included many more exotics than others (Tables 1,2, Fig. 2). In absolute numbers, more than half of the non-native species belonged to 3 of the 54 locallyoccurring families (Poaceae: 27\% of aliens; Asteraceae: 21\%; Brassicaceae: 13\%) (Table 1, Fig. 2). In addition, the proportion of species of exotic origin varied significantly among families $\left(\mathrm{X}^{2}{ }_{10}=33.13: \mathrm{p}<0.001\right.$; small families pooled to maintain average expected value $\sim 5$ ). This non-random association is evidence that groups of related species may bias the raw results, and suggests that phylogenetically independent comparisons may be useful.

Grassland (85-90\% of the CPER) contained the highest total number of species, followed by riparian zones and roadsides (each 1-2\% of the CPER) (Table 2). Riparian and roadside habitats, roadsides and disturbed sites, and roadsides and grassland habitats shared numerous species (Jaccard coefficient $>0.2$ ); with these exceptions, relatively few species were found in more than one habitat type (Table 2). Exotics were overrepresented on roadsides, in riparian zones, and in disturbed sites: 50\% of roadside species, $28 \%$ of riparian species, and $25 \%$ of the species in disturbed sites were aliens (Tables 1,2, Fig. 3). No exotics occurred primarily in grassland, whereas $45 \%$ of native species were recorded from this habitat (Tables 1,2, Fig. 3). A greater fraction of natives than aliens also occurred in ravines. 


\section{Comparative analyses}

Both sets of comparative analyses generated similar numbers of phylogenetically independent contrasts: 29 for the analyses based on the Flora of the Great Plains vs. 27 for those based on Chase et al. (1993). As might be expected, more than half of these contrasts (31) occurred within Poaceae, Asteraceae, or Brassicaceae; only five contrasts involved more than one family. Both comparative analyses also generated very similar trends and patterns of significance (Fig. 3). Both indicated that exotics were disproportionately likely to occur in riparian and roadside habitats and unlikely to occur in grassland habitats, while natives showed a marginally non-significant $(\mathrm{p}=0.07)$ tendency to occur disproportionately in ravines (Fig. 3). No significant associations with disturbed sites were detected. 


\section{Discussion}

$\underline{\text { Raw (uncorrected) habitat associations }}$

Exotic plants often are especially successful at exploiting disturbed or resource-rich habitats (Elton 1958; Mooney and Drake 1986; Crawley 1986, 1987; Tilman 1987; Drake et al. 1989; Pimm 1991; Hobbs and Huenneke 1992; Huston 1994; McIntyre and Lavorel 1994; Jefferies and Maron 1997), probably because these factors can reduce the severity of competition from native vegetation. Previous studies suggest that this model applies at the CPER. As is the case in many prairies, below-ground competition in the native-dominated CPER grassland is severe (Milchunas et al. 1992; Hook et al. 1994; Aguilera and Lauenroth 1995), but the addition of water or nutrients ameliorates belowground conditions and allows aliens to invade (Milchunas et al. 1989, 1990; Milchunas and Lauenroth 1995). Physical disturbance may have a similar effect, reducing belowground competition by breaking up the nearly continuous root network (Coffin and Lauenroth 1988; Milchunas and Lauenroth 1989; Hook et al. 1994; Aguilera and Lauenroth 1995). In addition, physical disturbance may directly favour exotics with ruderal life histories (dispersal, dormancy, phenology, etc.) while excluding competitive but disturbance-intolerant natives adapted to the surrounding, stable grassland. In contrast, the effects of grazing apparently differ from those of other forms of "disturbance". Grazing locally reduces the abundance of exotic species, probably because it removes grazing-intolerant invaders and leads to increased below-ground competition (Milchunas and Lauenroth 1989; Milchunas et al. 1989, 1990, 1992). Milchunas et al. (1990) have argued that the absence of grazing constitutes a disturbance in this historically grazed ecosystem.

Our results indicate that these effects translate to the landscape scale. No aliens occurred primarily in grazed but otherwise undisturbed grassland, while disturbed sites (areas around water sources, construction zones, etc.) supported disproportionate numbers of exotics. Exotics also were disproportionately likely to occur on roadsides, 
which typically are disturbed to some extent (as suggested by their high Jaccard similarity to disturbed sites), often are protected from grazing, and may trap drainage and experience runoff from the road's surface (as suggested by their Jaccard similarity to riparian habitats). Similarly, riparian habitats supported large numbers of exotics, probably reflecting both greater water availability and trampling disturbance by cattle (Vallentine 1990; Fleischner 1993).

One implication of these results is that roadsides and riparian zones are acting as avenues for the initial spread of exotic species (e.g., Saunders and Hobbs 1991; Simberloff et al. 1992; Hobbs 1992; Malanson 1993; U.S. Congress OTA 1993; de Waal et al. 1994). One case in point is cheatgrass, Bromus tectorum. This Eurasian species has occupied thousands of square kilometres of the North American intermountain west, replacing native species and changing fire regimes and other ecosystem characteristics (Mack 1981; Mack and Thompson 1982; Mack 1986; D’Antonio and Vitousek 1992). In contrast, shortgrass steppe has been relatively little invaded by B. tectorum or most other exotic species (Mack and Thompson 1982). To date, B. tectorum has been scarce in most habitats of the CPER, but its abundance has been increasing on roadsides in recent years (CPER and LTER staff, pers. com.). In 1995, B. tectorum founded numerous large new populations in shortgrass steppe close to roads, probably because that year's near-record early-season rainfall temporarily reduced water stress. Roadsides have allowed this grass to arrive, persist, and possibly to spread into the vegetation and seed banks of grassland habitats.

Phylogenetically independent comparisons between natives and exotics

In the only other study to date which has used phylogenetically independent contrasts to compare natives and exotics, Crawley et al. (1996) demonstrated that exotics in Britain differed from related natives in having larger seeds, taller stature, more pronounced seed dormancy, and smaller distributions. However, Crawley et al's (1996) analysis did not reveal a phylogenetically-independent effect for the single 
habitat variable considered (altitude). In contrast, we found that associations between geographic origin and riparian, roadside, and grassland habitats all were significant even after correcting for phylogenetic confounding, indicating that the ability to exploit these habitats reliably separated aliens from related natives. Conversely, roadside and riparian habitats have been invaded by many different groups of exotics, rather than one or a few specialized clades; for these habitats, knowing the relationships of a potential invader may add little to efforts to predict its invasiveness.

Results of phylogenetically independent comparisons need not resemble the results of uncorrected analyses (Felsenstein 1985; Ridley 1989; Harvey and Pagel 1991, Harvey and Purvis 1991; Gittleman and Luh 1992; Miles and Dunham 1993). In our study, however, these two types of analysis produced very similar results, indicating that the trends evident in the flora as a whole were not products of taxonomic biases, but instead distinguished natives from even related exotics. The chief way in which our raw and corrected analyses differed was the disappearance of the marginally significant "raw" associations between exotics and disturbed sites, and between natives and ravine habitats. As discussed below, this loss of significance probably reflects the loss of power associated with this class of test. It also suggests that, at least at this time, the weak association between exotics and disturbed sites in the raw dataset is largely attributable to a few clades of closely-related disturbance-dependent species (e.g., Kochia and Salsola spp., Melilotus spp., Bromus spp: Table 1). These may simply be the first nonnatives to exploit these habitats; their dominance may well diminish over time as more exotics arrive.

\section{Methodological Issues}

Our study illustrates two difficulties associated with phylogenetically independent comparisons. First, their accuracy ultimately depends on the accuracy of the phylogeny upon which they are based. We compensated for phylogenetic uncertainty by using a method of analysis which makes the fewest assumptions possible about tree shape and 
branch length. In addition, we assessed the robustness of our analyses by comparing two different classification schemes; like Kelly and Woodward (1996), we found that our "phylogenetic" and "taxonomic" trees produced very similar results. Second, comparative analyses (especially robust ones) may entail significant losses of information and statistical power (Harvey and Pagel 1991; Harvey and Purvis 1991; Lord et al. 1995; Westoby et al. 1995a,b). These losses are undesirable, but are costs of transforming non-independent data into a smaller but unconfounded set of contrasts. In the FGP and Chase analyses respectively, our methods reduced 337 species to 29-27 paired comparisons, and 34\%-42\% of species directly contributed to no contrast whatsoever. Despite these limitations, the power of our analyses was sufficient for the identification of consistent and highly significant phylogenetically independent associations between exotic plants and roadside and riparian habitats, and between natives and grassland habitats.

\section{Transportation biases}

The ultimate reason that so many exotics prosper in roadsides, riparian zones, and (to a lesser extent) disturbed sites may reflect patterns of transportation, rather than differences in invasibility (Simberloff 1986; Heywood 1989; Rejmánek 1989; Mack 1996; Williamson 1996; Williamson and Fitter 1996). The species most likely to be transported to new sites or regions by humans probably are those already occurring in mesic regions with large human populations. These species are more likely to be adapted to wet areas or to human or cattle disturbance than to pristine, semi-arid CPER habitats. Species which might thrive in undisturbed grassland (e.g., exotics from remote, semi-arid regions of Eurasia) may be less likely to be transported, and perhaps unsuited to the more mesic coastal areas of North America which otherwise could act as stepping-stones. Similarly, if exotics initially arrive via corridor habitats, then the contrast between the high diversity of exotics in roadside and riparian areas and the apparent invasion resistance of grasslands may diminish over time as more species 
spread from these corridors into new territory. B. tectorum may be only one of many exotics spreading into shortgrass steppe in this manner. Invasion is an ongoing process; as is true for most studies, our results most strongly capture the behaviour of the earliest invaders ( 100 year timescale). In years to come, these patterns may well be modified as more invaders arrive and spread. 


\section{Acknowledgements}

This is a contribution of the Shortgrass Steppe Long-Term Ecological Research Program (NSF BSR-8114822). Research was supported in part by NSF DEB-9496331 and a

Packard Fellowship to J.B. We also would like to thank the Rangeland Resources Research Unit of the USDA Agricultural Research Service, which administers the CPER. I. Parker, T. Wootton, W. Lauenroth, T. Juenger, M. Weis, and an anonymous reviewer helpfully commented on earlier versions of this manuscript. 


\section{References}

Ackerly, D.D. 1997. Plant life histories: a meeting of phylogeny and ecology. Trends Ecol. Evol. 12: 7-9.

Ackerly, D.D., and Donoghue, M.J. 1995. Phylogeny and ecology reconsidered. J. Ecol. 83: 727-734.

Aguilera, M.O., and Lauenroth, W.K. 1995. Influence of gap disturbances and type of microsites on seedling establishment in Bouteloua gracilis. J. Ecol. 83: 87-97.

Armstrong, D.P., and Westoby, M. 1993. Seedlings from large seeds tolerate defoliation better: a test using phylogenetically independent contrasts. Ecology 74: 1092-1100.

Baker, H. 1974. The evolution of weeds. Annu. Rev. Ecol. Sys. 5: 1-24.

Baum, D. 1994. rbcL and seed-plant phylogeny. Trends Ecol. Evol. 9: 39-41.

Brooks, D.R., and McLennan, D.A. 1991. Phylogeny, ecology, and behavior. University of Chicago Press, Chicago, IL.

Burt, A. 1989. Comparative methods using phylogenetically independent contrasts. Ox. Surv. Evol. Biol. 6: 33-53.

Chase, M.W. et al. 1993. Phylogenetics of seed plants: an analysis of nucleotide sequences from the plastid gene $r b c L$. Ann. Mo. Bot. Gard. 80: 528-580.

Clayton, W.D., and Renvoize S.A. 1986. Genera graminum: grasses of the world. Kew Bulletin Additional Series 13.

Coffin, D.P., and Lauenroth W.K. 1988. The effects of disturbance size and frequency on a shortgrass plant community. Ecology 69: 1609-1617.

Crawley, M.J. 1986. The population biology of invaders. Phil. Trans. R. Soc. Lond. B 314: 711-736. 
Crawley, M.J. 1987. What makes a community invasible? In Colonization, succession and stability. Edited by A.J. Gray, M.J. Crawley, and P.J. Edwards. Blackwell, Oxford. pp. 429-453.

Crawley, M.J., Harvey, P.H., and Purvis, A. 1996. Comparative ecology of the native and alien floras of the British Isles. Phil. Trans. R. Soc. Lond. B 351: 1251-1259.

Cronk, Q.C.B., and Fuller, J.L. 1995. Plant invaders: the threat to natural ecosystems. Chapman and Hall, London.

Cronquist, A. 1981. An integrated system of classification of flowering plants. Columbia University Press, New York, NY.

Daehler, C.C., and Strong, D.R. 1993. Prediction and biological invasions. Trends. Ecol. Evol. 8: 380-381.

D'Antonio, C.M., and Vitousek, P.M. 1992. Biological invasions by exotic grasses, the grass/fire cycle, and global change. Annu. Rev. Ecol. Syst. 23: 63-87.

de Waal, L.C., Child, L.E., Wade, P.M., and Brock, J.H. 1994. Ecology and management of invasive riverside plants. John Wiley and Sons, Chichester. Drake, J.A., Mooney, H.A., di Castri, F., Groves, R.H., Kruger, F.J., Rejmánek, M., and Williamson, M., editors. 1989. Biological invasions: a global perspective (SCOPE 37). Wiley, Chichester.

Dawkins, R. 1982. The extended phenotype : the long reach of the gene. Oxford University Press, Oxford.

Donoghue, M.J., and Ackerly, D.D. 1996. Phylogenetic uncertainties and sensitivity analyses in comparative biology. Phil. Trans. R. Soc. Lond. B 351: 241-1249.

Elton, C.S. 1958. The ecology of invasions by plants and animals. Chapman and Hall, London. 
Felsenstein, J. 1985. Phylogenies and the comparative method. Am. Nat. 125: $1-15$.

Felsenstein, J. 1988. Phylogenies and quantitative characters. Annu. Rev. Ecol. Syst. 19: 445-471.

Fleischner, T.L. 1993. Ecological costs of livestock grazing in western North America. Cons. Biol. 8: 629-644.

Gittleman, J.L., and Luh, H.-K. 1992. On comparing comparative methods. Annu. Rev. Ecol. Sys. 23: 383-404.

Great Plains Flora Association. 1986. Flora of the Great Plains. University Press of Kansas, Lawrence, KS.

Grime, P. 1979 Plant strategies and vegetation processes. Wiley, Chichester.

Harvey, P.H., and Pagel, M.D. 1991. The comparative method in evolutionary biology. Oxford University Press, Oxford.

Harvey, P.H., and Purvis, A. 1991. Comparative methods for explaining adaptations. Nature 351: 619-624.

Heady, H.F. 1988. Valley grassland. In Terrestrial vegetation of California (new expanded edition). Edited by M.G. Barbour, and J. Major. Wiley, New York, NY. pp. 491-514.

Heady, H.F., Bartolome, J.W., Pitt, M.D., Savelle, G.D., and Stroud, M.C. 1992. California prairie. In Ecosystems of the world 8A: natural grasslands. Edited by R.T. Coupland. Elsevier, Amsterdam, pp. 313335.

Heywood, V.H. 1989. Patterns, extents and modes of invasions by terrestrial plants. In Biological invasions: a global perspective (SCOPE 37). Edited by J.A. Drake, H.A. Mooney, F. di Castri, R.H. Groves, F.J. Kruger, M. Rejmánek, and M. Williamson. Wiley, Chichester. pp. 31-60. 
Hobbs, R.J. 1992. The role of corridors in conservation: solution or bandwagon? Trends Ecol. Evol. 7: 389-392.

Hobbs, R.J., and Huenneke, L.F. 1992. Disturbance, diversity, and invasion: Implications for conservation. Cons. Biol. 6: 324-337.

Hook, P.B., Lauenroth, W.K., and Burke, I.C. 1994. Spatial patterns of roots in a semiarid grassland: abundance of canopy openings and regeneration gaps. J. Ecol. 82: 485-494.

Huston, M.A. 1994. Biological diversity: the coexistence of species on changing landscapes. Cambridge University Press, Cambridge.

Jefferies, R.L., and Maron, J.L. 1997. The embarrassment of riches: atmospheric deposition of nitrogen and community and ecosystem processes. Trends Ecol. Evol. 12: 74-78.

Kelly, C.K., and Woodward, F.I. 1996. Ecological correlates of plant range size: taxonomies and phylogenies in the study of plant commonness and rarity in Great Britain. Phil. Trans. R. Soc. Lond. B 351: 1261-1269.

Lodge, D.M. 1993. Biological invasions: lessons for ecology. Trends Ecol. Evol. 8: 133-137.

Lord, J., Westoby, M., and Leishman, M. 1995. Seed size and phylogeny in six temperate floras: constraints, niche conservatism, and adaptation. Am. Nat. 146: 349-364.

Mack, R.N. 1981. Invasion of Bromus tectorum L. into western North America: an ecological chronicle. Agro-ecosystems 7: 145-165.

Mack, R.N. 1986. Plant invasions into the intermountain west. In Ecology of biological invasions of North America and Hawaii. Edited by H.A. Mooney, and J.A. Drake. Springer-Verlag, New York, NY. pp. 191-213. 
Mack, R.N. 1989. Temperate grasslands vulnerable to plant invasions: characteristics and consequences. In Biological invasions: a global perspective (SCOPE 37). Edited by J.A. Drake, H.A. Mooney, F. di Castri, R.H. Groves, F.J. Kruger, M. Rejmánek, and M. Williamson. Wiley, Chichester. pp. 155-179.

Mack, R.N. 1996. Predicting the identity and fate of plant invaders: emergent and emerging approaches. Biol. Cons. 78: 107-121.

Mack, R.N., and Thompson, J.N. 1982. Evolution in steppe with few large, hooved mammals. Am. Nat. 119: 757-773.

Malanson, G.P., 1993. Riparian landscapes. Cambridge University Press, Cambridge.

McIntyre, S., and Lavorel, S. 1994. Predicting richness of native, rare, and exotic plants in response to habitat and disturbance variables across a variegated landscape. Cons. Biol. 8: 521-531.

McKitrick, M.C. 1993. Phylogenetic constraint in evolutionary theory: has it any evolutionary power? Annu. Rev. Ecol. Sys. 24: 307-330.

Milchunas, D.G., and Lauenroth, W.K. 1989. Three-dimensional distribution of plant biomass in relation to grazing and topography in the shortgrass steppe. Oikos 55: 82-86.

Milchunas, D.G., and Lauenroth, W.K. 1995. Inertia in plant community structure: state changes after cessation of nutrient-enrichment stress. Ecol. Appl. 5: 452-458.

Milchunas, D.G., Lauenroth, W.K., and Chapman, P.L. 1992. Plant competition, abiotic, and long- and short-term effects of large herbivores on demography of opportunistic species in a semiarid grassland. Oecologia 92: 520-531. 
Milchunas, D.G., Lauenroth, W.K., Chapman, P.L., and Kazempour, M.K. 1989. Effects of grazing, topography, and precipitation on the structure of a semiarid grassland. Vegetatio 80: 11-23.

Milchunas, D.G., Lauenroth, W.K., Chapman, P.L., and Kazempour, M.K. 1990. Community attributes along a perturbation gradient in a shortgrass steppe. J. Veg. Sci. 1: 375-384.

Miles, D.B., and Dunham, A.E. 1993. Historical perspectives in ecology and evolutionary biology: the use of phylogenetic comparative analyses. Annu. Rev. Ecol. Sys. 24: 587-617.

Mooney, H.A., and Drake, J.A., editors. 1986. Ecology of biological invasions of North America and Hawaii. Springer-Verlag, New York, NY.

Pickett, S.T.A., and White, P.S. editors. 1985. The ecology of natural disturbance and patch dynamics. Academic Press, Orlando, FL.

Pimm, S.L. 1987. Determining the effects of introduced species. Trends Ecol. Evol. 2: 106-108.

Pimm, S.L. 1991. The balance of nature? University of Chicago Press, Chicago, IL.

Purvis, A., and Rambaut, A. 1995a. Comparative analysis by independent contrasts (CAIC): an Apple Macintosh application for analyzing comparative data. Computer Appl. Biosciences 11: 247-251.

Purvis, A., and Rambaut, A. 1995b. Comparative analysis by independent contrasts (CAIC): a statistical package for the Apple Macintosh. User's Guide. 
Pyßek, P. 1995. On the terminology used in plant invasion studies. In Plant invasions: general aspects and special problems. Edited by P. Pyßek, K. Prach, M. Rejmánek, and M. Wade. SPB Academic Publishing, Amsterdam. pp. 71-81.

Rejmánek, M. 1989. Invasibility of plant communities. In Biological invasions: a global perspective (SCOPE 37). Edited by J.A. Drake, H.A. Mooney, F. di Castri, R.H. Groves, F.J. Kruger, M. Rejmánek, and M. Williamson. Wiley, Chichester. pp. 369-388.

Ridley, M. 1989. Why not to use species in comparative tests. J. Theor. Biol. 136: $361-364$.

Ruesink, J.L., Parker, I.M., Groom, M.J., and Karieva, P. 1995. Reducing the risks of nonindigenous species introductions. Bioscience 45: 465-477.

Saunders, D.A., and Hobbs, R.J., editors. 1991. The role of corridors. Surrey Beatty, Chipping Norton.

Simberloff, D. 1986. Introduced insects: a biogeographic and systematic perspective. In Ecology of biological invasions of North America and Hawaii. Edited by H.A. Mooney, and J.A. Drake. Springer-Verlag, New York, NY. pp. 3-26.

Simberloff, D., Farr, J.A., Cox, J., and Mehlman, D.W. 1992. Movement corridors: conservation bargains or poor investments? Cons. Biol. 6: 493504.

Sims, P.L. 1988. Grasslands. In North American terrestrial vegetation. Edited by M.G. Barbour, and W.D. Billings. Cambridge University Press, Cambridge. pp. 265-286.

Sousa, W.P. 1984. The role of disturbance in natural communities. Ann. Rev. Ecol. Sys. 15: 353-391. 
Thompson, K. 1994. Predicting the fate of temperate species in response to human disturbance and global change. In Biodiversity, Temperate Ecosystems and Global Change. Edited by T.J.B. Boyle, and C.E.B. Boyle. Springer-Verlag, Berlin. pp. 61-76.

Tilman, D. 1987. Secondary succession and the pattern of plant dominance along experimental nitrogen gradients. Ecol. Monogr. 57: 189-214.

U.S. Congress, Office of Technology Assessment 1993. Harmful nonindigenous species in the United States (OTA-F-565). U.S. Government Printing Office, Washington, D.C.

Vallentine, J.F. 1990. Grazing management. Academic Press, San Diego, CA.

Vitousek, P.M., D’Antonio, C.M., Loope, L.L., and Westbrooks, R. 1996. Biological invasions as global environmental change. American Scientist 84: 468-478.

Vitousek, P.M., and Walker, L.R. 1989. Biological invasion by Myrica faya in Hawai'i: plant demography, nitrogen fixation, ecosystem effects. Ecol. Monogr. 59: 247-265.

Vitousek, P.M., Walker, L.R., Whiteaker, L.D., Mueller-Dombois, D., and Mattson, P.A. 1987. Biological invasion by Myrica faya alters ecosystem development in Hawaii. Science 238: 802-804.

Westoby, M., Leishman, M., and Lord, J. 1995a. On misinterpreting the ‘phylogenetic correction’. J. Ecol. 83: 531-534.

Westoby, M., Leishman, M., and Lord, J. 1995b. Further remarks on phylogenetic correlation. J. Ecol. 83: 727-734.

Williamson, M. 1996. Biological Invasions. Chapman and Hall, London.

Williamson, M.H., and Fitter, A. 1996. The characters of successful invaders. Biol. Cons. 78: 163-170. 
Table 1. The 52 exotic vascular plants occurring at the CPER at the time of this study. Indicated are life history $(\mathrm{A}=$ Annual, $\mathrm{B}=$ Biennial, $\mathrm{P}=$ Perennial $)$ and occurrence in each habitat type ( 1 = occurs in this habitat; 0 = does not occur $)$.

\begin{tabular}{|c|c|c|c|c|c|c|c|}
\hline \multirow[t]{3}{*}{ Family } & \multirow[t]{3}{*}{ Species } & \multirow{3}{*}{$\begin{array}{l}\text { Life } \\
\text { history }\end{array}$} & \multicolumn{5}{|l|}{ Habitat } \\
\hline & & & & & & & \\
\hline & & & Riparian & Roadside & Ravine & Disturbed & Grassland \\
\hline \multirow[t]{11}{*}{ Asteraceae } & Arctium minus & B & 1 & 0 & 0 & 0 & 0 \\
\hline & Centaurea repens & $\mathrm{P}$ & 1 & 1 & 0 & 0 & 0 \\
\hline & Cichorium intybus & A & 0 & 1 & 0 & 0 & 0 \\
\hline & Cirsium arvense & $\mathrm{P}$ & 1 & 1 & 0 & 0 & 0 \\
\hline & Crepis capillaris & A & 1 & 0 & 0 & 0 & 0 \\
\hline & Lactuca serriola & A & 1 & 1 & 0 & 0 & 0 \\
\hline & Scorzonera laciniata & A & 0 & 1 & 0 & 0 & 0 \\
\hline & Sonchus oleraceus & A & 1 & 1 & 0 & 0 & 0 \\
\hline & Taraxacum officinale & $\mathrm{P}$ & 1 & 1 & 0 & 0 & 0 \\
\hline & Tragopogon dubius & $\mathrm{B} / \mathrm{P}$ & 0 & 1 & 0 & 1 & 0 \\
\hline & Tragopogon pratensis & $\mathrm{B} / \mathrm{P}$ & 0 & 1 & 0 & 1 & 0 \\
\hline Boraginaceae & Cynoglossum officinale & B & 1 & 0 & 0 & 0 & 0 \\
\hline \multirow[t]{7}{*}{ Brassicaceae } & Alyssum alyssoides & A & 0 & 1 & 0 & 0 & 0 \\
\hline & Camelina microcarpa & A & 1 & 1 & 0 & 0 & 0 \\
\hline & Capsella bursa-pastoris & $\mathrm{A} / \mathrm{B}$ & 1 & 1 & 0 & 0 & 0 \\
\hline & Chorispora tenella & $\mathrm{P}$ & 0 & 1 & 0 & 0 & 0 \\
\hline & Descurainia sophia & $\mathrm{A} / \mathrm{B}$ & 1 & 1 & 0 & 1 & 0 \\
\hline & Sisymbrium altissimum & A & 1 & 1 & 0 & 1 & 0 \\
\hline & Thlaspi arvense & A & 1 & 1 & 0 & 0 & 0 \\
\hline \multirow[t]{5}{*}{ Chenopodiaceae } & Chenopodium glaucum & A & 1 & 0 & 0 & 0 & 0 \\
\hline & Corispermum hyssopifolium & A & 0 & 0 & 1 & 0 & 0 \\
\hline & Kochia scoparia & A & 1 & 1 & 0 & 1 & 0 \\
\hline & Salsola collina & A & 0 & 1 & 0 & 1 & 0 \\
\hline & Salsola iberica & A & 1 & 1 & 0 & 1 & 0 \\
\hline Convolvulaceae & Convolvulus arvensis & $\mathrm{P}$ & 0 & 1 & 0 & 0 & 0 \\
\hline
\end{tabular}




\section{Table 1. Continued.}

\begin{tabular}{|c|c|c|c|c|c|c|c|}
\hline \multirow[t]{3}{*}{ Family } & \multirow[t]{3}{*}{ Species } & \multirow{3}{*}{$\begin{array}{l}\text { Life } \\
\text { history }\end{array}$} & \multicolumn{5}{|l|}{ Habitat } \\
\hline & & & & & & & \\
\hline & & & Riparian & Roadside & Ravine & Disturbed & Grassland \\
\hline \multirow[t]{5}{*}{ Fabaceae } & Medicago lupulina & $\mathrm{A} / \mathrm{P}$ & 1 & 1 & 0 & 0 & 0 \\
\hline & Melilotus alba & $\mathrm{P}$ & 0 & 1 & 0 & 1 & 0 \\
\hline & Melilotus officinalis & B & 0 & 1 & 0 & 1 & 0 \\
\hline & Trifolium pratense & $\mathrm{P}$ & 1 & 0 & 0 & 0 & 0 \\
\hline & Trifolium repens & $\mathrm{P}$ & 1 & 0 & 0 & 0 & 0 \\
\hline Geraniaceae & Erodium cicutarium & A & 1 & 1 & 0 & 0 & 0 \\
\hline Malvaceae & Malva neglecta & $\mathrm{P}$ & 1 & 1 & 0 & 0 & 0 \\
\hline Plantaginaceae & Plantago major & $\mathrm{P}$ & 1 & 0 & 0 & 0 & 0 \\
\hline \multirow[t]{14}{*}{ Poaceae } & Agropyron cristatum & $\mathrm{P}$ & 0 & 1 & 0 & 1 & 0 \\
\hline & Agropyron repens & $\mathrm{P}$ & 1 & 0 & 0 & 0 & 0 \\
\hline & Agrostis stolonifera & $\mathrm{P}$ & 1 & 0 & 0 & 0 & 0 \\
\hline & Bromus inermis & $\mathrm{P}$ & 0 & 1 & 0 & 1 & 0 \\
\hline & Bromus japonicus & A & 1 & 1 & 0 & 0 & 0 \\
\hline & Bromus tectorum & A & 1 & 1 & 0 & 1 & 0 \\
\hline & Dactylis glomerata & $\mathrm{P}$ & 1 & 1 & 0 & 0 & 0 \\
\hline & Echinochloa crusgalli & A & 1 & 1 & 0 & 0 & 0 \\
\hline & Elymus junceus & $\mathrm{P}$ & 0 & 1 & 0 & 1 & 0 \\
\hline & Eragrostis cilianensis & A & 0 & 1 & 0 & 1 & 0 \\
\hline & Phleum pratense & $\mathrm{P}$ & 1 & 0 & 0 & 0 & 0 \\
\hline & Poa compressa & $\mathrm{P}$ & 1 & 1 & 0 & 0 & 0 \\
\hline & Polypogon monspeliensis & A & 1 & 0 & 0 & 0 & 0 \\
\hline & Setaria viridis & A & 1 & 0 & 0 & 0 & 0 \\
\hline \multirow[t]{2}{*}{ Polygonaceae } & Polygonum aviculare & A & 0 & 1 & 0 & 1 & 0 \\
\hline & Rumex crispus & A & 1 & 0 & 0 & 0 & 0 \\
\hline Portulacaceae & Portulaca oleracea & A & 1 & 0 & 0 & 0 & 0 \\
\hline Scrophulariaceae & Linaria dalmatica & $\mathrm{P}$ & 1 & 1 & 0 & 0 & 0 \\
\hline Zygophyllaceae & Tribulus terrestris & A & 0 & 1 & 0 & 0 & 0 \\
\hline
\end{tabular}


Table 2. (a) Species occurring in each habitat type. (b) Jaccard similarity coefficients comparing the set of species occurring in each habitat type. Jaccard values are defined as (number of species occurring in both habitat a and habitat b) / (number of species occurring in habitat a and/or habitat b). Total species richness $=52$ aliens and 285 natives, but a given species may occur in more than one habitat type.

Riparian Roadside Ravine Disturbed Grassland

(a) Number of species

$\begin{array}{lccccc}\text { Natives } & 88 & 37 & 30 & 44 & 150 \\ \text { Aliens } & 35 & 37 & 1 & 15 & 0 \\ \text { Total } & 123 & 74 & 31 & 59 & 150\end{array}$

(b) Jaccard values

\begin{tabular}{|c|c|c|c|}
\hline Riparian & 0.216 & 0.000 & 0.028 \\
\hline Roadside & - & 0.010 & 0.243 \\
\hline Ravine & & - & 0.000 \\
\hline
\end{tabular}

Disturbed

0.222 


\section{Figure Captions}

Fig. 1. Calculation of two selected phylogenetically independent contrasts from the Chase et al. (1993) tree, according to the methods described in the text. The independent variable is origin $(\mathrm{A}=$ Alien, $\mathrm{N}=$ Native); the dependent variable is habitat $(\mathrm{R}=$ Riparian, $\mathrm{O}=$ Other $)$. Contrast $\mathrm{C}_{8}=(0 / 1-4 / 5)=-0.8$; contrast $\mathrm{C}_{11}=(1 / 1-0 / 1)=$ 1.0. The mean phylogenetically independent contrast $=\left(C_{8}+C_{11}\right) / 2=(-0.8+1.0) / 2=$ 0.1 ; the overall uncorrected (raw) "contrast" $=(1 / 2-4 / 6)=-0.17$. In this example, the phylogenetically independent contrasts indicate a positive association between aliens and riparian habitats, while the uncorrected overall contrast indicates a negative association.

Fig. 2. Taxonomic distribution of native and alien vascular plant species on the CPER checklist.

Fig. 3. Association between habitat and origins. Shown are uncorrected ("Raw") associations and phylogenetically independent contrasts based on two different classification schemes ("FGP" = Flora of the Great Plains; "Chase" = Chase et al. 1993). "Raw" associations illustrate the proportion of alien (positive values) or native (negative values) species associated with that habitat. "FGP" and "Chase" values illustrate the number of contrasts indicating an association with alien (positive) or native (negative) species. Significance values indicate whether each set of contrasts differs from 0 (no association); *: $\mathrm{p}<0.05 ;{ }^{* *}: \mathrm{p}<0.01 ; * * *$ : $<<0.001$. 


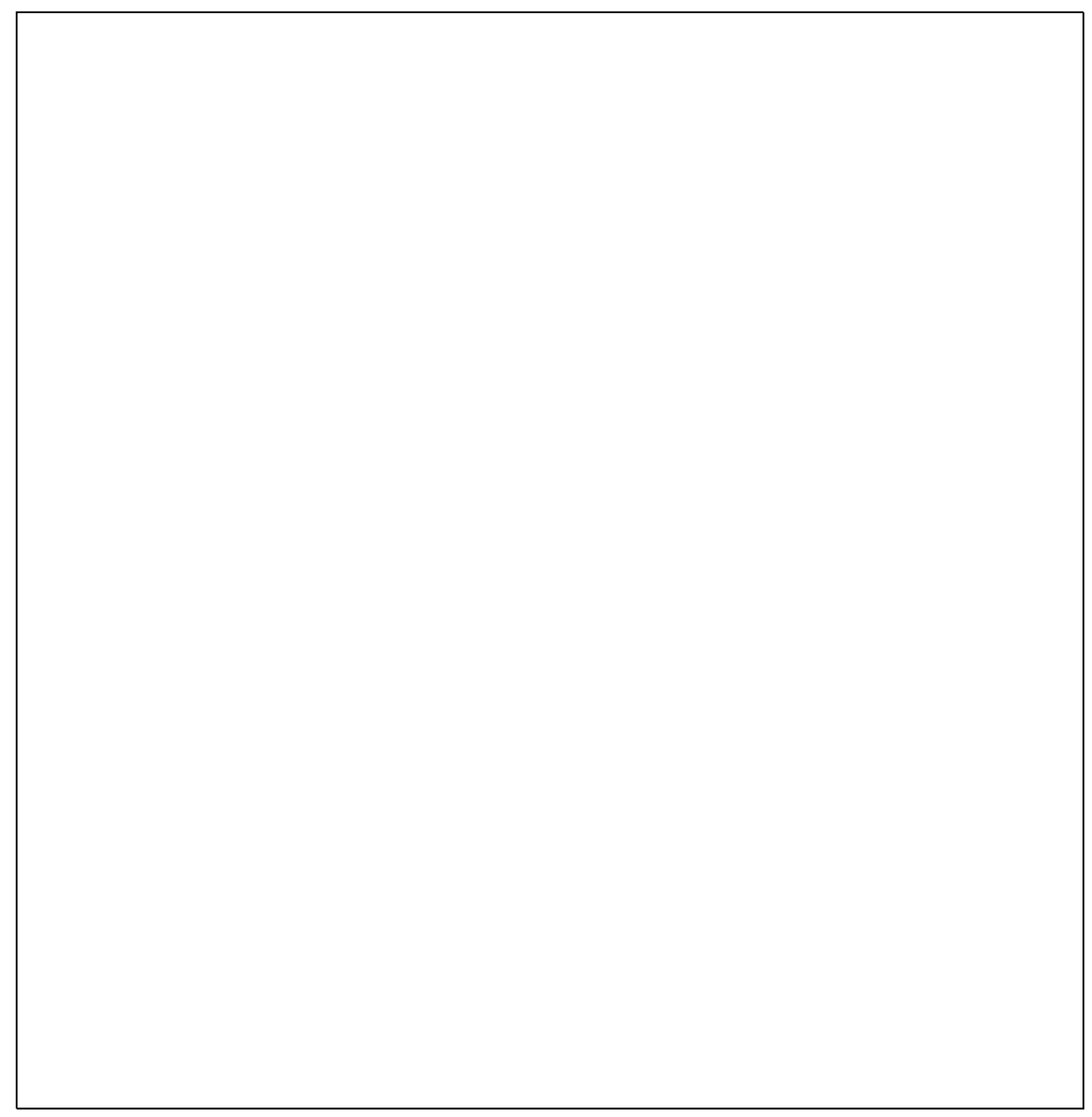



